\title{
Urban solid waste incorporated in brick soil-cement: process and cure
}

\section{Incorporação de resíduos sólidos urbanos em tijolos solo-cimento: processos e cura}

\author{
Alessandro Campos ${ }^{1}$; Fernando Celso de Campos ${ }^{2}$
}

\begin{abstract}
Investigate the reuse of urban solid waste (USW) becomes important in the present day due to environmental problems. Develop an experimental project using a mixture of soil-cement bricks with traces without addition of USW and dashes with addition of USW, provides procedures for stress tests after the molding and healing of these bricks, and consider the feasibility of using element, in order to determine what best trait, stabilization and method of healing. The proposal proved to be feasible and possible to reduce the amount of non-renewable material in soil-cement bricks production incorporating tire rubber shavings and dust of marbles and granites. By proposing a dash is ideal for the production of soil-cement bricks, provides subsidies for the replicability of this product, as well as the use of tire chips and powder of marble and granite, to minimize the use of these materials by recycling, showing be compatible with the existing rules requiring. Use grated tire minimizes your disposal in the environment and through the insertion of marble and granite powder in the mixture, offers better resistance to compression, bricks being viable production of this product with this material.
\end{abstract}

Keywords: Reuse of urban solid waste. Brick soil cement. Materials through recycling.

\section{Resumo}

Investigar a reutilização do municipal resíduos sólidos urbanos (RSU) torna-se importante nos dias de hoje devido a problemas ambientais. Desenvolver um projeto experimental, usando uma mistura de tijolos de solo-cimento com traços sem adição de RSU e traços com adição de RSU, fornece procedimentos para testes de estresse após a moldagem e cura destes tijolos e considerar a viabilidade do uso de elemento, a fim de determinar o melhor traço, estabilização e método de cura. A proposta provou para ser viável e possível reduzir a quantidade de material não-renováveis na produção de tijolos de solo-cimento incorporando raspas de borracha de pneu e pó de mármores e granitos. Propondo um traço ideal para a produção de tijolos de solo-cimento, fornece subsídios para a replicabilidade deste produto, bem como o uso de chips de pneus e pó de mármore e granito, para minimizar o uso destes materiais por reciclagem, mostrando ser compatível com as regras existentes que exigem. Pneu ralado uso minimiza sua disposição no ambiente e através da inserção de pó de mármore e granito na mistura, oferece a melhor resistência à compressão, tijolos sendo viável produção deste produto com este material.

Palavras-chave: Reuso de resíduos sólidos urbanos. Tijolo solo-cimento. Reciclagem de materiais.

\footnotetext{
${ }^{1}$ Me. Prof., Dpto. Arquitetura e Urbanismo, UCDB, Campo Grande, MS, Brasil; E-mail: alessandro@ucdb.br

2 Dr. Prof., Dpto Engenharia de Produção, UNIMEP, S.B. d'Oeste, SP, Brasil; E-mail: fernando.campos@ unimep.br
} 


\section{Introduction}

In brazilian cities, a problem faced is urban solid waste (USW), which points out that it is necessary to take care of environmental aspects due to the effects generated in relation to process and products to construction industry (SÁ et al., 2013).

Based on the principles of sustainable development (SD) presents that concept to the commitment to harmonize social and economic development with conservation of the environment (SANTOS; RITA DE CÁSSIA; FASSONI, 2007). In this way, recycling can be adequate in the implementation of alternative materials as inputs for the construction industry (SHAHIN; HONG, 2010), which makes possible to assign a reduced cost in its application.

With the intention of providing economic, social and environmental performance based on SD, that elements adapt to in the environmental, social and economic spheres through tools and concepts of TRIPLE BOTTOM LINE (TBL), created by John Elkington (TRIPLE. . ., 2009).

Initially conceived as a concept of social responsibility, TBL resembles a number indicator and reporting issuer, so the TBL concept can provide indexes such as:

- Assess social, environmental and economic performance;

- Assess social, environmental and economic impacts;

- Index environmental quality and social justice;

- Propagate social progress, ecological balance and environmental health;

- Propagate equity of sustainable social, environmental and economic development.

TBL suggests evaluating environmental impacts by proposing actions based on the assumptions raised, evaluating the social impact and suggesting practices to those involved with environmental integration and social responsibility, not only focusing on the economic value of the product but also on the environmental and social value with what this product can generate, with an emphasis on the environment, lifestyles and livelihoods (VANCLAY, 2004).

Decisions about TBL aim to analyze a set of feasible actions where planning should be efficient in order to investigate a better equitable distribution to identify bottlenecks, formulate the problem and generate results in an attempt to conserve resources (KUCUKVAR; TATARI, 2013).

To promote conservation of natural resources for minimize environmental impacts, it contemplates considering equity in relation to social responsibility, minimizing costs and maximizing environmental conservation goals (HALPERN et al, 2013), increasing efforts to achieve sustainability (RENUKAPPA; EGBU; GOULDING., 2012).

The construction sector presents itself as a major consumer of natural resources, to which $80 \%$ of the resources are employed in the US construction industry, renovating buildings and infrastructure systems so that the industry consumes more natural resources than any another industrial branch, so civil construction has significant impacts on the environment and, therefore, must undergo transformations (GRAEDEL; ALLENBY, 2010; KUCUKVAR; TATARI, 2013; SHARRARD; MATTHEWS; RIES, 2008).

Waste can be noticed in the construction industry through the improper disposal of materials at the end of their useful life and by proposing integration suggested in the TBL those that to intent recycle for the development of products, whether in the economic, social or environmental sphere, involving different sectors, one can avoid that the system is compromised (SEGANTINI; WADA, 2011).

Recycling is intended to reintroduce waste materials into the production process so that they can be transformed into new products. In this way, sustainable development (SD) has as its general principle the concept of immediate preservation of natural resources for future generations to enjoy these resources. This principle was developed and published initially by Elkington (TRIPLE..., 2009), based on the economic, social and environmental tripod, extending into new concepts, presented as TBL.

The TBL should be a philosophy, with the involvement of the people in the use of the materials used, so that the productive systems are configured in integrated systems based on economic issues (FLEURY; FLEURY, 2008), taking into account due ethical care with interpersonal relationships and cultural aspects of the community and those involved in the manufacture of goods, products, and the environment (JACKSON, 2003), to plan SD concepts through TBL bias, it is intended to achieve with reuse and/or recycling a reduction of USW (SLAPER; HALL, 2011).

This work proposes to produce soil bricks based on the principles of TBL, with the addition of tire shavings and marbled residues, and proposes a brick model with recycled aggregates in the production process. This proposal to base on the fact that the differential between traces of bricks of soil of a trait using tire shavings and marble residues is considered. 
Therefore, when conducting a study on the feasibility of adding USW to the production of soil bricks based on empirical knowledge and bibliographical research (MIGUEL, 2012) since the natural soil is used, the proposal can contribute to address gaps in housing of social interest, by proposing initiatives such as self-construction, aligning the SD to the TBL.

\section{Reuse of materials}

Can be observed after their main use the devaluation of products, in the case of retread tires, that's has a "positive value", to which non-recoverable tires, that's have "negative value" (CEMPRE, 2018), so that it generates disorders, where they are deposited in irregularly shaped landfills and become attractive to rodents and insects (MARQUES; NIRSCHL; AKASAKI, 2006), (FIORITI; INO; AKASAKI, 2007).

Old tires when recycled, can be cut into slices and transformed into rubber powder by a mechanical granulation process, with lower cost and lower environmental impact, compared to the process with chemicals (CEMPRE, 2018).

In the life cycle of this product, residues from its scrap generation generate raw material and produce consumer goods (CHEHEBE, 1997; NÓBILE，2003; ROCHA; JOHN, 2003), since these residues present great potential in construction, paving, among $26.5 \%$ are appropriately disposed of according to regulations (ANIP, 2014), minimizing the degradation of the environment.

The use of tire scrapings for the construction industry in the production of concrete presents itself as a perfectly acceptable alternative (MARTINS, 2004), because the concrete is the most used construction material in civil construction in Brazil and apply in construction alternative materials may minimization of the use natural materials of non-renewable.

In trying to use this waste, several studies are developed to improve the properties through the inclusion of USW of cement products to minimize environmental impacts, to provide alternatives with technical and environmental benefits (ANIP, 2014), as the waste from marble works can be used, so that are discarded in the form mud slabs, which in the dry state, results in dust.

Soil bricks with marbled residues may be feasible, therefore, the compressive strength decreases with the increase of the residue content (LIMA, 2010), which caused changes in the technical properties of soil bricks samples, considering their minimum resistance to compression, confirming its application (RIBEIRO; HOLANDA, 2014).
Actions aimed at waste management should consider planning and classification, characterization, quantification, treatment and recovery processes, as well as storage locations according to safety, transport and cost norms (BRASIL, 2010). That the regulates the correct management of USW, with goals known as the 3R's (reduction, reuse, recycling), which defines that the USW generator must be the responsible for the management of this waste, and therefore, the USW coming from the civil construction, can be applied in construction works, infrastructure, landfills or other engineering works.

The construction sector factors, it is noticed that there are recent problems with residues (VILHENA, 2009), since the rapid growth of the population resulted in an increase of residues related of the garbage accumulation, and the urban cycle, began to attract animals transmitting diseases and possible epidemics (MORAES, 2012).

In this way, it is necessary to consider environmental care due to the scarcity of raw materials analyzing the needs, as well as being attentive to the effects that it generates in relation to its works, products and processes (SÁ et. al, 2013). And the SD concept has an preserving natural ecosystems, rationalizing resources, participation of the local people, waste reduction and waste recycling (SANTOS; RITA DE CÁSSIA; FASSONI, 2007).

As the TBL comments that a planning tool for the construction of sustainable societies to environmental protection, social justice and economic efficiency, so that they can be applied in small scale, such as a house, or large scale, such as businesses or cities (ELKINGTON, 1997).

To propose less environmental impact, (TRIPLE..., 2009) based on the concept of the 3 (three) P's:

1. People: Pleasant work environment and economic activity without compromising the economic, environmental and social performance their surroundings;

2. Planet: Mitigate negative impacts, and;

3. Profit: A positive economic result of a company, without devastating the environment taking profit (SLAPER; HALL, 2011).

The TBL through environmental management with supply chains and market, corporate culture through profit, integration of people and preservation of the planet seeks social equity (GIMENEZ; SIERRA; RODON, 2012). And the distribution of wealth among all those involved in the process and fostering sustainable communities, valuing not only profits, but also those involved (VANCLAY, 2004), with formal approaches to indicate values, and 
in this way can be minimized costs and maximized the objectives (HALPERN et al, 2013).

Unifying that concept and presenting an environmentally compatible, socially just and economically profitable system, creates conditions for its permanence in the market from production processes aligned to TBL (HALL, 2011; SAVITZ, 2013, MOORE, 1996).

Thus, TBL concepts should be presented as a model of organizational management, since it indicates the integration of the partners, by agreeing and maintaining fidelity of this concept, not only applying an operating system (ELKINGTON, 2001). By making companies more prepared in the division of responsibilities in processes with the trust factor, not only economic capital but social capital is defined (ELKINGTON, 1998), since applying techniques without integration suggested in the TBL, the whole system can be compromised (SEGANTINI; WADA, 2011).

For these concepts to be applied, the changes don't be focused in management tools to the processes, but changes in cultural, economic and even in the construction sector, as well as consuming large amounts generate a lot of waste.

\section{Applicability}

For the construction industry, it is important to emphasize the implementation of quality programs, so that professional skills, product quality, social and educational quality can be effectively exercised, extending to their quality to which the use of quality tools and programs can help increase the level of qualification, so that the TBL allows this incentive (REGINO, 2010).

In order to determine the amount of materials applied in the construction of bricks, soil with reference traces should have parameters (standard), which defined with a trial process, to investigated about the fact, as well as the soil characterization, based on Brazilian standards for soil bricks (ABNT, 1986, 1984a, 1988a, 1988b, 1994).

Adding rasps to the mix provides a higher mass, volume and attempts to achieve the minimum resistance specified for soil bricks based on current standards, so that the use of these tire chips in the production of nonstructural brick without compromising the mechanical strength of the bricks and without increasing the consumption of cement is $13 \%$ of volume of tire shavings (FIORITI; AKASAKI, 2004; PEREIRA; FAZZAN; FREITAS, 2015).

By replacing $7.5 \%$ of the sand mass with the tire, the results are more satisfactory in terms of the mechanical performance of concrete in terms of compressive strength
(AKASAKI; FIORITI; NIRSCHL, 2002). However, for rubber quantities of $15 \%$ to $20 \%$, the modified concrete became more difficult to knead and mold the specimens, impairing the quality of the pieces (YONEYAMA, 2002).

By adding materials such as quarry basalt fines, these contribute to increase compressive strength by increasing the packing factor (FILER effect), because this it fills the voids between the aggregates (LOPES, 2005).

Through actions by aligning theory and practice through standardized tools and procedures. To define the standard, a methodology is presented from the structuring to solve problems (SÁFFARO, 2007) with the steps:

1. Defining a strategy;

2. Involve methods and objectives to achieve it;

3. Implement this strategy;

4. Verify the implementation and results of this strategy;

5. Adjust the abnormalities in the exercise of the pattern or design a new plan.

Thus, from the rationalization using modular bricks, it is intended to reduce waste, resulting in a faster construction process, saving materials and labor by pressing the mixture for bricks soil (SILVA; CASTRO, 2011).

A building with sustainable principles considers the life cycle of materials used, with lower consumption of energy, water and other natural resources, and considers social responsibilities, energy efficiency and ecological awareness (FIGUEROLA, 2008).

In the process of production of soil bricks, their compaction must be adequate, and thus ensure that the material reaches a good density and stabilizes, providing an appropriate mechanical resistance to use of the product (CAMPOS; BRITO; NASCIMENTO, 2018). Any type of soil can be used, and more appropriate soils have 45 to $50 \%$ sand content, and according to the ratio between clay and sand, this soil must be balanced (SEGANTINI; WADA, 2011), to which this balance was done with the mixtures researched and presented for stabilization of the material and later molding of the bricks.

\section{Materials and Methods}

To develop this work in order to produce a brick of soil by adding the shavings of tires and marbled residues (marble and granite powder), an experimental plan was elaborated using a reference mixture, with traces of $1: 10$ (cement: soil). 
That important to emphasize the influence in environmental cycle by using USW to envisage reduction of environmental liabilities and can influence the economic cycle by proposing in this production use of low-cost equipment and easy operation, with the possibility of generating a large volume of bricks produced.

This fact to be highlighted is in relation to inputs discarded in conjunction with local materials (soil), aiming at minimizing the use of non-renewable raw material (sand) used in large-scale construction tends to become scarcer and more expensive. In this way, some experimental planning practices will be used to formulate procedures to produce the bricks using suggested USW and to reach answers, with parameters of the raw material and components used, with a synthesis to design of experiments (DOE) according to Table 1.

In the case of the bricks proposed for this work, the variables can be controllable, and others cannot be controlled, so they can be evaluated so that the tests can be replicated, and new products defined.

Variables that can be controlled are:

i) Cement;

ii) Water;

iii) Time e;

iv) Type of cure.

Non-controllable variables are:

i) Soil;

ii) Tire scrapers (must be sifted for grain size adjustment);

iii) Marble waste (marble and granite powder).

Therefore, the non-controlled variables such as soil, tyre scrapings and marble and granites residues must have a specific particle size for this type of brick and must be sifted to reach the desired particle size. When considering the specific characteristics in the characterization of the materials, these variables become controlled, favoring the type of cure for hardening according to the current norms and also the types of pressing with the load determined in the setup of machine.

These considerations (TBL principles, dosages, standardization of measurements and technical characteristics) show that both the acquisition of natural inputs and USW, even when they depend on external agents, establish a pattern in the productive process by suggesting a routine that can avoid errors by repeating processes and tasks by applying already acquired knowledge.

The dosing procedures for the preparation of the soil test specimens were established in the preparation of a trace, to determine the amount of materials together with the water cement factor, with traces of 1:10 (cement: soil), to determine the stabilization of the product, as requested by the Brazilians standard, ABNT (1994). Portland cement CPII-Z32 was used, soil from the Dom Bosco Catholic University (Campo Grande - MS) and water from the public supply network.

With this, it is possible to verify the samples for the proposed cures, being cured in the open air, irrigated and in a humid chamber, obtained minimum resistances required by the standard, which is the individual value of the upper specimens $1.7 \mathrm{MPa}$ and with an average of 2 $\mathrm{MPa}$, to the simple compression at 7 days according to Table 2.

In order to develop the research, the USW were added gradually to determine the quantity to be achieved in the proposal of partial replacement of tire shavings and marbled residues (marble powder and granite), so that the obtained without USW was satisfactory and its use may be recommended. In this way, starting from the granulometry verified and in the tests performed resulted in the adequate quantity through tests of resistance to compression maintaining the quality of the product.

For soil characterization, the current norms applied by ABNT for solid ceramic bricks and hollow soil-cement blocks were used as parameters, since the soils should be characterized according to the standards (ABNT, 1986, 1988b).

In the soil granulometric analysis, the procedure for checking and determining soil granulometry, as well as the values found in the dry mass retained in the sieve and their respective percentages, can be verified in Table 3.

A portion of soil in Natura was separated and dried and subsequently debared with the aid of and a porcelain mortar with hand of Gral and a sieve with mesh \#4 (4.8mm).

The granulometric curve resulting from the fine sieving of the soil, Figure 1, being $100 \%$ thru in the \#4 sieve $(4.8 \mathrm{~mm})$, obtained the result that the soil employed has a characteristic of the small aggregate.

To used scraps tires, in the study (ÖZKUL; BAYKAL, 2007), they reported the inclusion of $10 \%$, with granulometry retained between the sieve \#4 and \#10, gave peak intensity comparable to that of the mixture without 
Table 1 - Experimental planning of the research

\begin{tabular}{|c|c|c|}
\hline Guidelines & Situation & Attitudina \\
\hline The recognition Problem & $\begin{array}{c}\text { Brick soil with low USW } \\
\text { utilization }\end{array}$ & $\begin{array}{c}\text { Bibliographic research on the } \\
\text { subject }\end{array}$ \\
\hline The choice of factors and levels & $\begin{array}{l}\text { Use of natural and recycled } \\
\text { materials }\end{array}$ & $\begin{array}{c}\text { Determine procedures for } \\
\text { collection and use of materials }\end{array}$ \\
\hline $\begin{array}{c}\text { The selection of the response } \\
\text { variable }\end{array}$ & $\begin{array}{l}\text { Parameters for production of soil } \\
\text { bricks }\end{array}$ & $\begin{array}{l}\text { Make reference traces } \\
\text { Product Stabilization }\end{array}$ \\
\hline $\begin{array}{c}\text { The choice of experimental } \\
\text { planning }\end{array}$ & $\begin{array}{l}\text { Determine parameters for } \\
\text { performance improvement }\end{array}$ & $\begin{array}{l}\text { Different method of healing } \\
\text { Resistance check }\end{array}$ \\
\hline $\begin{array}{c}\text { The realization of the } \\
\text { experiment }\end{array}$ & $\begin{array}{c}\text { Use of USW for brick planting } \\
\text { and optimization }\end{array}$ & $\begin{array}{l}\text { Experiments with new traits } \\
\text { Resistance check }\end{array}$ \\
\hline $\begin{array}{l}\text { Conclusions and } \\
\text { recommendations }\end{array}$ & $\begin{array}{l}\text { Obtaining bricks with improved } \\
\text { performance }\end{array}$ & $\begin{array}{l}\text { Applicability and uses } \\
\text { Commercial Potential }\end{array}$ \\
\hline
\end{tabular}

Source: The authors.

Table 2 - Result of the compressive strength test at 07 days and 28 days (CAMPOS; BRITO; NASCIMENTO, 2018)

\begin{tabular}{ccc}
\hline Healing & $\begin{array}{c}\text { Resist } \\
\text { (Mpa) }\end{array}$ & $\begin{array}{c}\text { Resist } \\
\text { (Mpa) }\end{array}$ \\
\hline & 4.30 & 6.98 \\
NATURAL AiR & 5.30 & 6.53 \\
Average-7 days/28 days & 5.30 & 7.06 \\
(Mpa) 5.18/6.87 & 5.87 & 6.89 \\
\hline & 5.20 & 7.43 \\
MOBILE CHAMBER & 5.48 & 7.54 \\
Average-7 days/28 days & 5.15 & 5.30 \\
(Mpa) 5.28/6.37 & 5.26 & 5.00 \\
\hline & 5.89 & 6.89 \\
WATERED & 5.51 & 6.38 \\
Average-7 days/28 days & 5.57 & 6.56 \\
(Mpa) 5.65/6.2 & 5.63 & 4.63
\end{tabular}

Source: The authors.

Table 3 - Soil Granulometric analysis

\begin{tabular}{ccccc}
\hline Sieve & $\begin{array}{c}\text { Aperture } \\
(\mathbf{m m})\end{array}$ & $\begin{array}{c}\text { Retained } \\
\text { soil (g) }\end{array}$ & $\begin{array}{c}\text { Retained } \\
\text { accumulated } \\
\text { soil (g) }\end{array}$ & $\begin{array}{c}\text { Passing } \\
\text { mass (\%) }\end{array}$ \\
\hline 16 & 1.19 & 0.07 & 0.07 & 99.94 \\
30 & 0.59 & 0.99 & 1.06 & 99.11 \\
40 & 0.42 & 5.14 & 6.20 & 94.83 \\
50 & 0.30 & 5.81 & 12.01 & 89.99 \\
100 & 0.15 & 13.19 & 25.20 & 79.00 \\
200 & 0.08 & 5.10 & 30.30 & 47.75 \\
\hline
\end{tabular}

Source: The authors. rubber. In this work, that fraction was used with passing tires zest in rice sieve \#4.8mm to the production of bricks, Figure 2, and has been ruled out the fraction retained in this sieve.

To make experiments with the reference traces, as a number of tire shavings were added to the soil mixture from the initial values with trace M01 in the ratio of 1:5:1 (cement: soil: shavings of tires) and $1.350 \mathrm{ml}$ of water, in the M02 trace in the ratio of 1:5:2 (cement: soil: shavings of tires) and $1.450 \mathrm{ml}$ of water, in the trace M03 in a proportion of $15: 3$ (cement: soil: shavings of tires) and water $1.650 \mathrm{ml}$, in trace M04 in the ratio of 1:6:2 (cement: soil: shavings of tires) and $1.950 \mathrm{ml}$ water, in the trace M05 1:7:2 (cement: soil: shavings of tires) and $2.600 \mathrm{ml}$ water and trace M06 1:8:2 (cement: soil: tire scraping) and $3.200 \mathrm{ml}$ water.

\section{Results and Discussion}

It was verified in the moldings of the specimens that when adding tire shavings, the workability of the mixture became more difficult, as well as its stabilization, and it was proved that in order to shape the bricks, the tire shavings must undergo a sifting process to suit its granulometry, by limiting the particle size in terms of material variation and product stability.

The variation occurred due to the type of use of the materials and test, determined the influence on the brick structure, due to its modifications, and all percentages of residue that will be used in the traces are in relation to the mass of cement. This way, the works cited in the body of the text, concluded that recycled aggregates, in the case of marbled residues have percentage of binders, with packing effect, also known as “filler". 
Figure 1 - Fine sieving plot of the soil

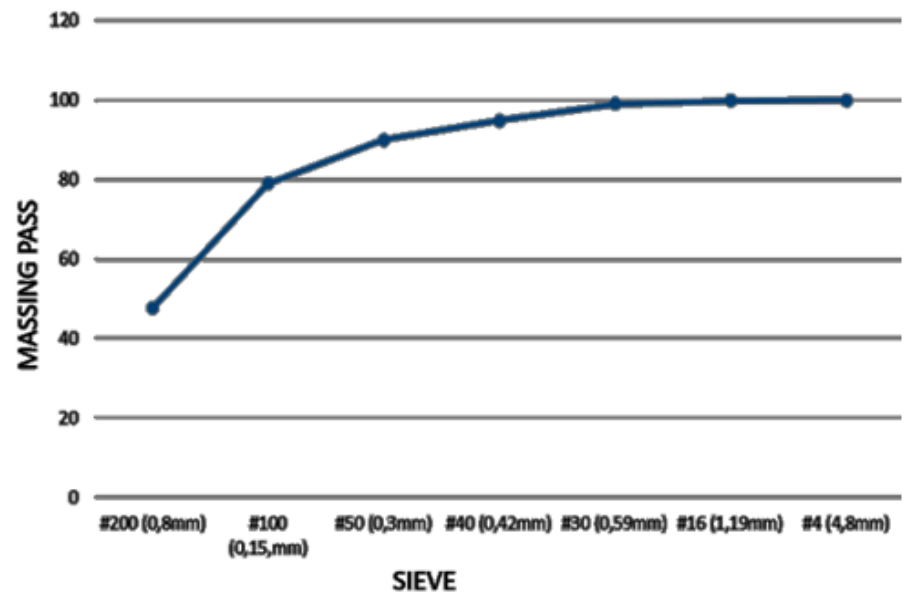

Source: The authors.

\section{SIEVE}

Figure 2 - Passing on rice sieve fraction (Used)

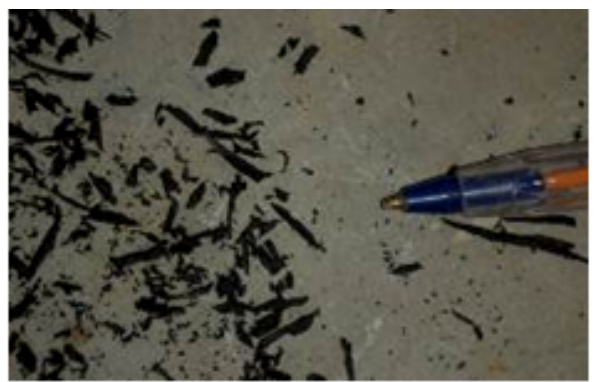

Source: The authors.

In the compressive strength test, it was noticed that some specimens broke (there were disintegration of the materials) and the proportion at low compressive strength was inverse to the amount of USW used.

It was possible to verify that by increasing the mixing of the tire scrapings, a lower compressive strength was obtained compared to the reference trait.

Therefore, by increasing the amount of soil in the mixture, it was obtained beyond the gain in the mechanical resistance of the bricks, there was also a greater quantity of bricks produced and lower consumption of cement.

These values could be verified and validated according to the theoretical baseline and the tests performed in the laboratory, indicating that the best trait presented was M06, and it was found that the greater the amount of rubber residues added, the lower the Compressive strength values, successively and proportionally inversely, according to Table 4.

In the tests of resistance to compression, some samples proved to be resistant and presented higher values than the previous ones, It was also verified that the unmolding of the test specimens was adequate and without unforeseen, since they practically did not present cracks or less homogenization, that show Figure 3.
Figure 3 - Withdrawal of the brick pressed in hydraulic equipment

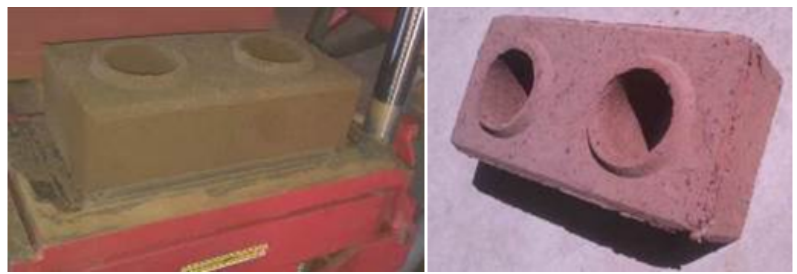

Source: The authors

The tests of compression, demonstrated that with the increase of the amount of water, there was no difficulty of kneading for the molding of the same ones, so that, the results obtained after the compaction test to obtain the values of compressive strength, from the addition of the tire shavings, gave subsidies to measure the quality of the different mixtures, and thus verify which ideal trait will serve as the reference model and directed to the realization of new tests using the powder of marble works according to Figure 4.

From the tear tests, reference was made to trace M06 (1:8:2) which provided compressive strength data from the 1:10 trace. From the tests that defined the trace M06 as reference and ideal trait (1:10), according to the orientation of ABNT (1984b, 1982, 1994), and having characteristic of experimental work, the production of bricks for reliability tests and validation of samples, ABNT (1994), must be checked 10 (ten) bricks for compression tests, tested in hydraulic press for tests of compressive strength after 07 days of age, to be determination of ideal trace using USW.

These bricks were made and tested later in the piece's own shape (whole brick), and to measure the amount of materials used, the values were determined from the mass by volume and unit mass, on the order of 3 
Table 4 - Results of the compressive strength test

\begin{tabular}{ccccccc}
\hline & \multicolumn{6}{c}{ Trace } \\
\cline { 2 - 7 } Samples & M01 & M02 & M03 & M04 & M05 & M06 \\
\hline CP 01 & $2.80 \mathrm{MPa}$ & $2.98 \mathrm{MPa}$ & $1.20 \mathrm{MPa}$ & $1.94 \mathrm{MPa}$ & $2.81 \mathrm{MPa}$ & $3.04 \mathrm{MPa}$ \\
CP 02 & $4.19 \mathrm{MPa}$ & $1.99 \mathrm{MPa}$ & $1.10 \mathrm{MPa}$ & $2.42 \mathrm{MPa}$ & $2.62 \mathrm{MPa}$ & $3.71 \mathrm{MPa}$ \\
CP 03 & $2.57 \mathrm{MPa}$ & $2.36 \mathrm{MPa}$ & $1.18 \mathrm{MPa}$ & $2.06 \mathrm{MPa}$ & $3.00 \mathrm{MPa}$ & $2.76 \mathrm{MPa}$ \\
CP 04 & $3.36 \mathrm{MPa}$ & $2.69 \mathrm{MPa}$ & $1.36 \mathrm{MPa}$ & $1.74 \mathrm{MPa}$ & $1.82 \mathrm{MPa}$ & $3.02 \mathrm{MPa}$ \\
CP 05 & $3.85 \mathrm{MPa}$ & $2.41 \mathrm{MPa}$ & $1.58 \mathrm{MPa}$ & $2.64 \mathrm{MPa}$ & $2.52 \mathrm{MPa}$ & $3.26 \mathrm{MPa}$ \\
CP 06 & $3.75 \mathrm{MPa}$ & $2.38 \mathrm{MPa}$ & $1.01 \mathrm{MPa}$ & $2.11 \mathrm{MPa}$ & $2.23 \mathrm{MPa}$ & $3.16 \mathrm{MPa}$ \\
CP 07 & - & - & - & $2.23 \mathrm{MPa}$ & $2.33 \mathrm{MPa}$ & $3.49 \mathrm{MPa}$ \\
CP 08 & - & - & - & - & $3.00 \mathrm{MPa}$ & $2.94 \mathrm{MPa}$ \\
CP 09 & - & - & - & - & - & $2.95 \mathrm{MPa}$ \\
CP 10 & - & - & - & - & - & $3.56 \mathrm{MPa}$ \\
\hline Average & $3.42 \mathrm{MPa}$ & $2.96 \mathrm{MPa}$ & $1.23 \mathrm{MPa}$ & $1.99 \mathrm{MPa}$ & $2.93 \mathrm{MPa}$ & $3.19 \mathrm{MPa}$ \\
\hline
\end{tabular}

Source: The authors.

Figure 4-Graph with unit mass volume of materials used in the adopted trait

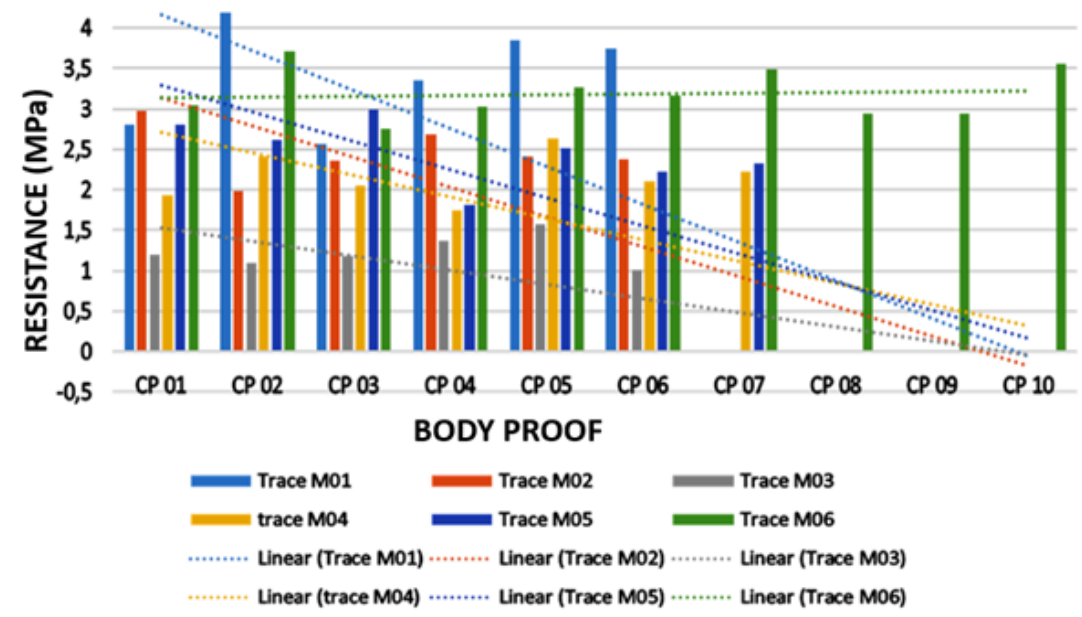

Source: The authors.

Aiming at a greater yield in the production of the liters (according to the available container), according to Table 5.

The unit mass at which stabilization of the produced brick was obtained, was obtained through laboratory tests with the intention of using a greater quantity of USW as aggregates in the mixture, according to Figure 5.

Figure 5 - Bricks soil-cement with USW - Mixture MM03
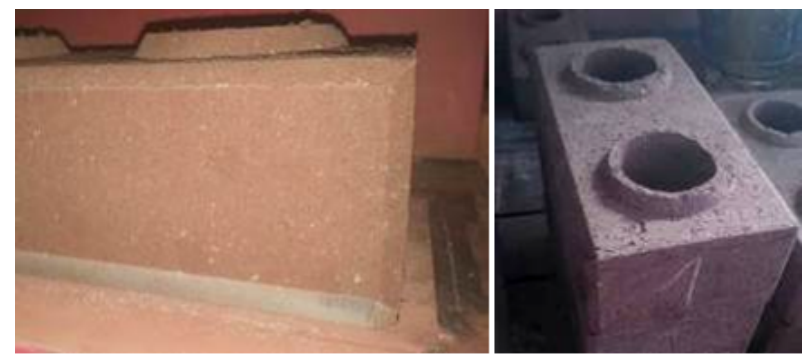

Source: The authors. bricks and less amount of cement in this mixture, so to obtain an improvement in the mechanical performance of these elements and economically viable, which can be verified a greater application of soil and marble residues in the mixture to obtain the ideal trace, according to Figure 6.

For the construction of the bricks with the proposed USW, the trait used will be the M06, with unit mass already defined, which allows the molding of the specimens with traces determined in the MM01 family with trace 1:8:0.5:1 (cement: soil: shaving of tires: marble and granite powder) and $3200 \mathrm{ml}$ water; family MM02 with trace 1:7:1:2 (cement: soil: shaving of tires: marble and granite powder) and $3200 \mathrm{ml}$ water; family MM03 with trace 1:7:0.5:2.5 (cement: soil: shaving of tires: marble and granite powder) and $3200 \mathrm{ml}$ water; family MM04 with trace 1:8:0.25:1.75 (cement: soil: shaving of tires: marble and 
Table 5 - Unit mass of the materials used in the MM03 family trace

\begin{tabular}{|c|c|c|c|c|c|}
\hline Material & Container & Volume & Unit mass & Total & Percentage \\
\hline Cement & $\phi=\frac{15 \mathrm{~cm}}{H}=17 \mathrm{~cm}$ & 3 liters & $3.68 \mathrm{Kgx} 1$ & $3.68 \mathrm{Kg}$ & $9.90 \%$ \\
\hline Soil & $\phi=\frac{15 \mathrm{~cm}}{H}=17 \mathrm{~cm}$ & 3 liters & $3.68 \mathrm{Kgx} 7$ & $25.76 \mathrm{Kg}$ & $69.28 \%$ \\
\hline Shavings of tires & $\phi=\frac{15 \mathrm{~cm}}{H}=17 \mathrm{~cm}$ & 3 liters & $1.18 \mathrm{Kgx} 0.5$ & $0.59 \mathrm{Kg}$ & $1.59 \%$ \\
\hline Powder (Marble/granite) & $\phi=\frac{15 \mathrm{~cm}}{H}=17 \mathrm{~cm}$ & 3 liters & $2.86 \mathrm{Kgx} 2.5$ & $7.15 \mathrm{Kg}$ & $19.23 \%$ \\
\hline Water & - & 3.2 liters & 3.2 liters & $3200 \mathrm{ml}$ water & \\
\hline
\end{tabular}

Source: The authors.

Figure 6 - Graph with unit mass volume of materials used in the adopted trait

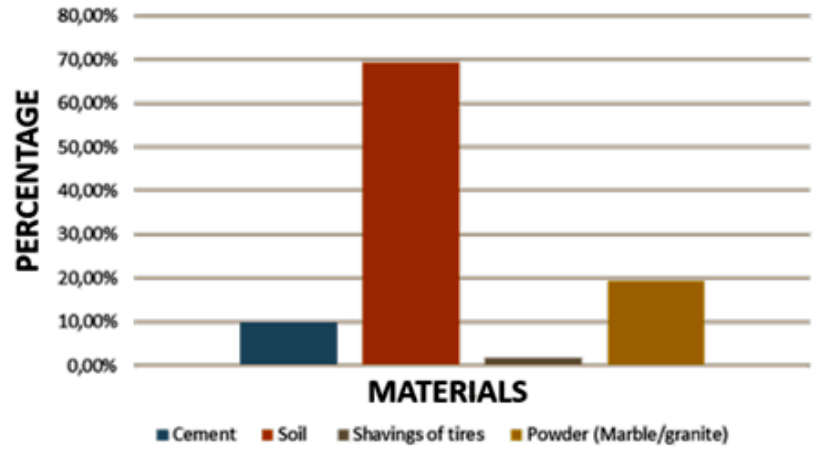

Source: The authors.

granite powder) and $3200 \mathrm{ml}$ water, that the general estimation was that this procedure could achieve the minimum resistance according to the recommendation of standards NBR 8492 and NBR 10833, of compressive strength with a mean of $2.00 \mathrm{MPa}$, according to Table 6.

According to the experimental data presented in relation to the dosages for determination of the trace in the making of the bricks of soil, and to the standardization of the units of measurement to arrive at the quantity of materials to produce a brick, in a first analysis the process proved adequate and an adequate value was reached for the MM03 trace, so that new tests were performed to validate the product with new lots produced, show the Figure 7.

These batches were cured by means of time drying and curing by means of a humid chamber, and thus, the comparatives will determine the best curing process, based previously on the results of table 2 , showed that the nonworking specimens of USW and cured in natural air, presented a mean of $5.18 \mathrm{MPa}$, and cured in a humid chamber, presented a mean of 5.27 MPa. In this way, new tests were performed to verify the compression resistance to the bricks have been tested since the stroke MM03 with air and natural healing of humid Chamber, according to Table 7.

To consider the bests average to analyzed bricks, the value consider in the tests above $1.7 \mathrm{MPa}$, to show the better were with the cured batch in the humid chamber, as well as the best results because their values were generally larger than the samples that were cured in the natural air, so that the trend line of the cured brick in the wet chamber obtained better results when compared to the natural air cured bricks according to Figure 8.

It was found that using USW were viable as aggregates in the mixture, aiming at a higher yield of the bricks and a lower amount of cement in this mixture, obtaining an improvement in the mechanical performance of these elements.

It can be observed in the graph presented that the bricks without the use of the RSUs, with natural air curing or curing by means of a humid chamber, obtained good resistance to compression, as well as the traces with addition of USW, denominated with the prefix "M" (scrap of tires) in their mixture, obtained 
Table 6 - Results of the compressive strength test

\begin{tabular}{ccccc}
\hline & \multicolumn{4}{c}{ Trace } \\
\cline { 2 - 5 } Samples & M01 & M02 & M03 & M04 \\
\hline CP 01 & $0.75 \mathrm{MPa}$ & $1.46 \mathrm{MPa}$ & $3.04 \mathrm{MPa}$ & $2.61 \mathrm{MPa}$ \\
CP 02 & $1.08 \mathrm{MPa}$ & $1.22 \mathrm{MPa}$ & $2.99 \mathrm{MPa}$ & $2.92 \mathrm{MPa}$ \\
CP 03 & $0.78 \mathrm{MPa}$ & $1.22 \mathrm{MPa}$ & $2.33 \mathrm{MPa}$ & $3.14 \mathrm{MPa}$ \\
CP 04 & $1.09 \mathrm{MPa}$ & $1.31 \mathrm{MPa}$ & $2.99 \mathrm{MPa}$ & $2.46 \mathrm{MPa}$ \\
CP 05 & $0.86 \mathrm{MPa}$ & $1.25 \mathrm{MPa}$ & $2.99 \mathrm{MPa}$ & $2.51 \mathrm{MPa}$ \\
CP 06 & $0.90 \mathrm{MPa}$ & $1.35 \mathrm{MPa}$ & $3.01 \mathrm{MPa}$ & $2.64 \mathrm{MPa}$ \\
CP 07 & $0.81 \mathrm{MPa}$ & $1.28 \mathrm{MPa}$ & $2.95 \mathrm{MPa}$ & $2.89 \mathrm{MPa}$ \\
CP 08 & $1.01 \mathrm{MPa}$ & $1.33 \mathrm{MPa}$ & $2.98 \mathrm{MPa}$ & $3.01 \mathrm{MPa}$ \\
CP 09 & $0.69 \mathrm{MPa}$ & $1.31 \mathrm{MPa}$ & $2.73 \mathrm{MPa}$ & $2.57 \mathrm{MPa}$ \\
CP 010 & $1.13 \mathrm{MPa}$ & $1.27 \mathrm{MPa}$ & $2.69 \mathrm{MPa}$ & $2.54 \mathrm{MPa}$ \\
\hline Average & $0.91 \mathrm{MPa}$ & $1.30 \mathrm{MPa}$ & $2.87 \mathrm{MPa}$ & $2.73 \mathrm{MPa}$ \\
\hline
\end{tabular}

Source: The authors.

Figure 7 - Graph with results of the compressive strength test

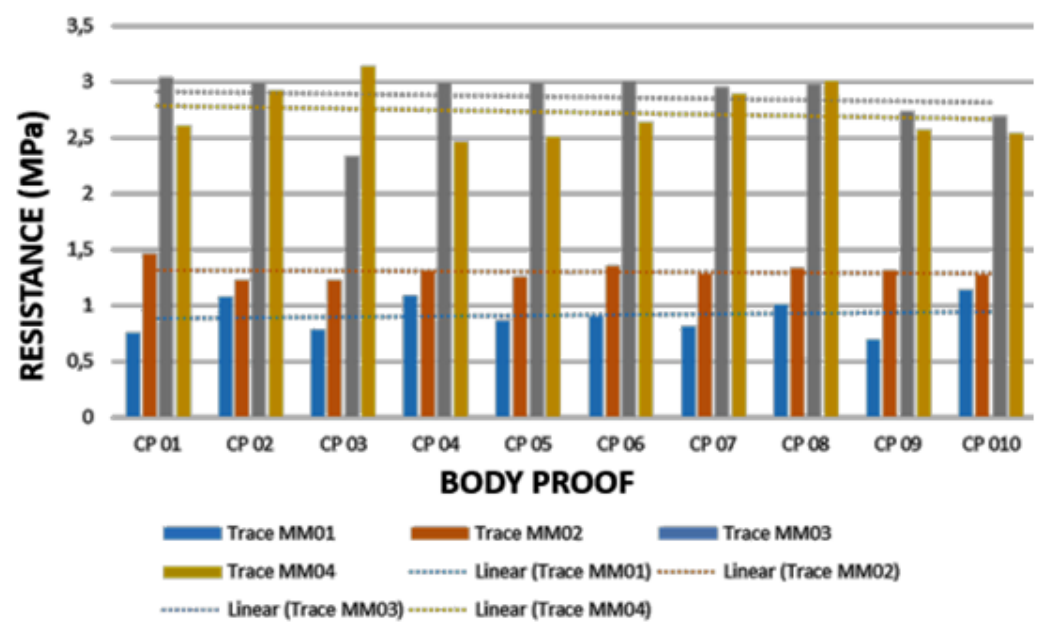

Source: The authors.

Figure 8 - Graph results of the compressive strength test (curing in a humid chamber/natural air)

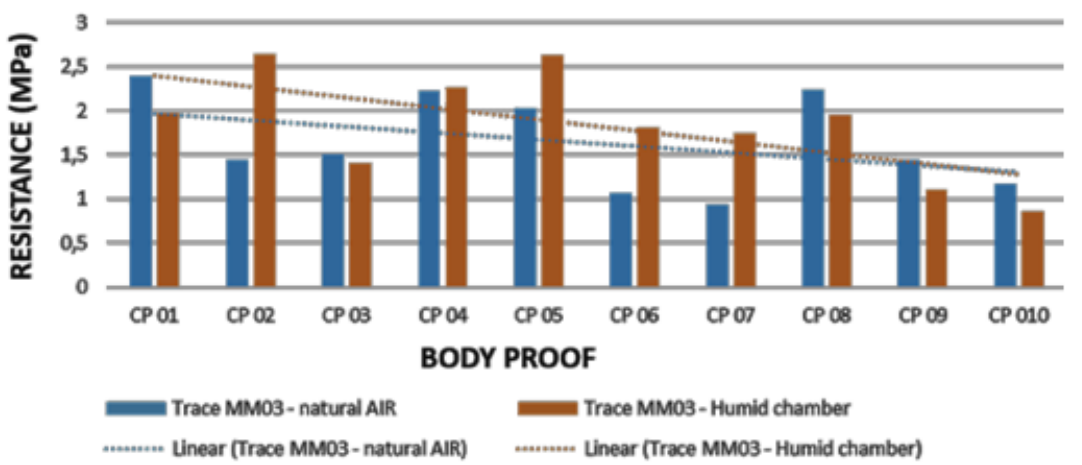

Source: The authors.

.......... Uinear (Trace MM03- Humid chamber)

variables in the obtained results, so that submitted to the tests of compression, the best results was the one of the family M06, since the use of the rasps in its mixture, was greater use of bricks in its molding and deformation of the part.

The bricks molded with the tire scrapers and marble powders that obtained the best results of the compression tests were from the family MM03, which generated a test to verify the curing in the natural air and through the humid chamber, which presented cured bricks in the moist chamber. According to the data obtained through the compression test, there was greater use of the MM03 trait of the bricks that were cured in the humid chamber, thus with the lowest variability in the results. 
Table 7 - Result of the compressive strength test (curing in a humid chamber/natural air)

\begin{tabular}{ccc}
\hline & \multicolumn{2}{c}{ Trace MM03 } \\
\cline { 2 - 3 } Samples & Natural AIR & Humid chamber \\
\hline CP 01 & $* 2.39 \mathrm{MPa}$ & $* 1.97 \mathrm{MPa}$ \\
CP 02 & $1.44 \mathrm{MPa}$ & $* 2.64 \mathrm{MPa}$ \\
CP 03 & $1.50 \mathrm{MPa}$ & $1.40 \mathrm{MPa}$ \\
CP 04 & $* 2.22 \mathrm{MPa}$ & $* 2.26 \mathrm{MPa}$ \\
CP 05 & $* 2.03 \mathrm{MPa}$ & $* 2.62 \mathrm{Mpa}$ \\
CP 06 & $1.06 \mathrm{MPa}$ & $* 1.80 \mathrm{Mpa}$ \\
CP 07 & $0.94 \mathrm{MPa}$ & $* 1.74 \mathrm{Mpa}$ \\
CP 08 & $* 2.23 \mathrm{MPa}$ & $* 1.95 \mathrm{MPa}$ \\
CP 09 & $1.44 \mathrm{MPa}$ & $1.10 \mathrm{MPa}$ \\
CP 010 & $1.17 \mathrm{MPa}$ & $0.85 \mathrm{MPa}$ \\
\hline Total average & $1.62 \mathrm{MPa}$ & $1.83 \mathrm{MPa}$ \\
\hline Average* & $2.21 \mathrm{MPa}$ & $2.14 \mathrm{MPa}$ \\
(Above 1.7MPa) & & \\
\hline
\end{tabular}

Source: The authors.

The pieces submitted to curing by means of the wet chamber, as verified in the literature review, and checked in the resistance tests, could be confirmed due to the number of pieces that were less resistant to the tests, since there were more pieces that presented results lower than that established by the standard with natural air curing compared to curing in a humid chamber, demonstrating the fragility in the curing time without the dry cure procedure, as the loss of water at the curing time will weaken the part in the time of cement hardening, decreasing its hardening.

\section{Conclusion}

Because of the waste of natural resources used in construction, to the intent of safeguarding natural resources, use of brick soil using materials from USW in their mixtures, open to new investigations that can, in fact, value the natural resources and reuse of disposal materials.

In this way, questioning the development of a product using alternative materials from discards without compromising its quality, generates opportunities to consider the production of soil cement bricks, using shaving tire and marble and granite powder, to which recycling can be favorable within this process, and presented itself as an excellent alternative with satisfactory results regarding the norms established by the Brazilians standard for non-structural ground elements.

The academic contribution of this work consists in the elaboration of an unknown trait to guide the process of discovery of knowledge and to collaborate with this trait using different USW aligned to the sustainable concepts. This process was conceived through the theoretical combination of methods using traditional materials such as soil and cement and alternatives such as those from discard.

From the sustainable aspects, the proposal meets the social requirements for using recycled materials, generating a production cycle to which the community can program collection systems and produce bricks as a joint effort, giving the stakeholders (community) of social responsibility. From the environmental point of view, it was verified that the destination of the appropriate form of the USW, becomes viable proven from the experimental tests arriving at an ideal trait, reducing the environmental liability generated by these residues. It was also verified in the economic aspect, when organizing the data obtained and verify the results, lower cost, minimization of errors and elimination of rework, reaching more production speed, less variability and better quality of the bricks.

Considering the originality of the work, from the laboratory experimentation with the evaluation of different traits, it gives an overview of the benefits in the process of knowledge discovery, when evaluating and understanding the subsidies from the presented results, contemplating the inclusion of materials from USW not in isolation, but different materials in the same trace.

This mixture resulted in higher compressive strength, so that the mixture should have adequate homogeneity prior to incorporation of the water in the kneading process, without forming lumps in the traces, and in the brick curing process, obtained better results if cured in chamber humid.

For data analysis and diagnosis, the production of the bricks can be performed using both traces with specific mass and unit mass, aligning in this way to a standardized process, and the quantity of the inputs can be used from the mass, as can be used by the amount (volume)

The bricks obtained in the tests of resistance to the compression results compatible with what the norms in force demand for non-structural bricks and also obtained quality and superficial appearance with good quality, to which it gives good acceptance for commercial use.

Therefore, user scraps tires in the mixture, claimed that the resistance of bricks is minor that bricks without this discharged material, but when the used with powder marble, the resistance of compression is better in the bricks soil-cement. 
Although the work focuses on the incorporation of residual materials into mixtures in the production of bricks, the proposed prototype presents conditions to develop other mixtures without losing quality. Therefore, to be replicated correctly and without variability, you must follow the same procedures, both for molding and for curing.

This proposal was feasible and demonstrated that it is possible to reduce cement in the production of these elements, as well as the insertion of a significant percentage of materials from non-renewable sources, increasing the final volume of the mass to produce soil bricks, which represents a major advance in the technology of producing artifacts with particularities of soil cement.

\section{Acknowledgments}

The Dom Bosco Catholic University for providing the laboratory of experiments.

\section{References}

AKASAKI, J. L.; FIORITI, C. F.; NIRSCHL, G. C. Estudo da viabilidade de produção dos blocos estruturais de concreto com adição de resíduos de borracha. In: Congresso Brasileiro, 44, 2002, Belo Horizonte, MG. Anais [...]. Belo Horizonte, MG: Instituto Brasileiro do Concreto, 2002.

ASSOCIAÇÃO BRASILEIRA DE NORMAS TÉCNICAS. NBR 10832. Fabricação de tijolo maciço de solocimento com utilização de prensa manual. Rio de Janeiro, $1992.8 \mathrm{p}$.

ASSOCIAÇÃO BRASILEIRA DE NORMAS TÉCNICAS. NBR 10833. Fabricação de tijolo e bloco de solocimento com utilização de prensa manual ou hidráulica: procedimento. Rio de Janeiro, 2012.

ASSOCIAÇÃO BRASILEIRA DE NORMAS TÉCNICAS. NBR 10834. Bloco vazado de solo-cimento sem função estrutural. Rio de Janeiro, 1994.

\section{ASSOCIAÇÃO BRASILEIRA DE NORMAS TÉCNI-} CAS. NBR 6457. Amostras de solos - preparação para ensaios de compactação e ensaios de caracterização. Rio de Janeiro, 1986.

ASSOCIAÇÃO BRASILEIRA DE NORMAS TÉCNICAS. NBR 6459. Solo - determinação do limite de liquidez. Rio de Janeiro, 1984a.
ASSOCIAÇÃO BRASILEIRA DE NORMAS TÉCNICAS. NBR 7180. Solo - determinação do limite de plasticidade. Rio de Janeiro, 1988a.

ASSOCIAÇÃO BRASILEIRA DE NORMAS TÉCNICAS. NBR 7181. Solo - análise granulométrica. Rio de Janeiro, 1988b.

ASSOCIAÇÃO BRASILEIRA DE NORMAS TÉCNICAS. NBR 8491. Tijolo maciço de solo-cimento: especificação. Rio de Janeiro, 1984b.

ASSOCIAÇÃO BRASILEIRA DE NORMAS TÉCNICAS. NBR 8492. Tijolo maciço de solocimento: determinação da resistência à compressão e da absorção de água: método de ensaio. Rio de Janeiro, 1982.

ASSOCIAÇÃO NACIONAL DA INDÚSTRIA DE PNEUMÁTICOS - ANIP. [2014].

BRASIL. Lei $n^{-}$12.305, 02 de agosto de 2010. Institui a Política Nacional de Resíduos Sólidos; altera a Lei no 9.605, de 12 de fevereiro de 1998; e dá outras providências. Brasília, DF: Presidência da República, 2010. Disponível em: <http://www.planalto.gov.br/ccivil_ 03/_ato20072010/2010/lei/112305.htm>. Acesso em: 22 dez. 2018.

CAMPOS, A.; BRITO, L. T.; NASCIMENTO JR., J. B. Tijolos de solocimento produzidos a partir do emprego de reuso de águas com diferentes métodos de cura aplicados na construção sustentável. In: Congresso Luso-Brasileiro de Materiais de Construção Sustentáveis, 3, 2018, Coimbra, PT. Anais [...]. Coimbra, PT, 2018.

CHEHEBE, J. R. B. Análise do ciclo de vida de produtos: ferramenta gerencial da ISO 14000. Rio de Janeiro: Qualitymark Editora, 1997.

\section{COMPROMISSO EMPRESARIAL PARA RECI-} CLAGEM - CEMPRE. O mercado para reciclagem. Available: http://cempre.org.br/artigo-publicacao/fichatecnica/id/7/pneus. Accessed on: 21 jul. 2018.

ELKINGTON, J. Cannibals with forks: the triple bottom line of twenty-first century business. São Paulo: Capstone, 1997.

ELKINGTON, J. Partnerships from cannibals with forks: the triple bottom line of 21 st. century business. Environmental Quality Management, Wheaton, IL, v. 8, n. 1, p. 37-51, 1998. 
ELKINGTON, J. The chrysalis economy: how citizen CEOs and corporations can fuse values and value creation. São Paulo: Capstone, 2001.

FIGUEROLA, V. Projeto Sustentável: arquitetura com foco na sustentabilidade requer integração de equipes e coordenação de um profissional especializado. Revista Techne, n. 133, abr. 2008

FIORITI, C. F.; AKASAKI, J. L. Fabricação de blocos estruturais de concreto com resíduos de borracha de pneus. Holos Environment, Rio Claro, SP, v. 4, n. 2, p. 145-156, 2004.

FIORITI, C. F.; INO, A.; AKASAKI, J. L. Avaliação de blocos de concreto para pavimentação intertravada com adição de resíduos de borracha provenientes da recauchutagem de pneus. Ambiente Construído, Porto Alegre, v. 7, n. 4, p. 43-54, out./dez. 2007.

FLEURY, A.; FLEURY, M. T. L. Estratégias empresariais e formação de competências: um quebra-cabeça caleidoscópico da indústria brasileira. 3. ed. São Paulo: Atlas, 2008 .

GIMENEZ, C.; SIERRA, V.; RODON, J. Sustainable operations: their impact on the triple bottom line. International Journal of Production Economics, Amsterdam, NL, v. 140, n. 1, p. 149-159, 2012.

GRAEDEL, T. E.; ALLENBY, B. R. Industrial ecology and sustainable engineering. Upper Saddle River, NJ: Prentice Hall, 2010.

HALL, T. J. The triple bottom line: what is it and how does it work? Indiana business review, Greenwich, v. 86 , n. 1, p. 4, 2011.

HALPERN, B. S.; KLEIN C. J.; BROWN, C. J.; BEGER, M.; GRANTHAM, H. S.; MANGUBHAI, S.; RUCKELSHAUS, M.; TULLOCH, V. J.; WATTS, M.; WHITE, C.; POSSINGHAM, H. P. Achieving the triple bottom line in the face of inherent trade-offs among social equity, economic return, and conservation. Proceedings of the National Academy of Sciences, Washington, DC, v. 110, n. 15, p. 6229-6234, 2013.

JACKSON, T. The chrysalis economy: how citizen CEOs and corporations can fuse values and value creation by John Elkington, 2001. Capstone, $\mathrm{xx}+284$ pp (hbk). ISBN 1-84112-142-8. Business Strategy and the Environment, v. 12, n. 5, p. 342-342, 2003.
KUCUKVAR, M.; TATARI, O. Towards a triple bottomline sustainability assessment of the US construction industry. The International Journal of Life Cycle Assessment, Landsberg, v. 18, n. 5, p. 958-972, 2013.

LIMA, R. C. O. Estudo da durabilidade de paredes monolíticas e tijolos de solo-cimento incorporados com resíduo de granito. 2010. Dissertação (Mestrado em Engenharia Civil e Ambiental) - Universidade Federal de Campina Grande, Campina Grande, PB, 2010.

LOPES, L. R. Avaliação da interferência dos finos no desempenho de concretos com resíduos de construção $e$ demolição. 2005. Dissertação (Mestrado em Engenharia de Edificações e Saneamento) - Universidade Estadual de Londrina, Londrina, PR, 2005.

MARQUES, A. C.; NIRSCHL, G. C.; AKASAKI, J. L. Propriedades mecânicas do concreto adicionado com borracha de pneus. Holos Environment, Rio Claro, SP, v. 6, n. 1, p. 31-41, 2006.

MARTINS, H. A. F. A utilização da borracha de pneus na pavimentação asfáltica. 2004. Trabalho de Conclusão de Curso (Bacharelado em Engenharia Civil) - Universidade Anhembi Morumbi, São Paulo, SP, 2004.

MIGUEL, P. A. C. Metodologia de pesquisa em engenharia de produção e gestão de operações. 3. ed. Rio de Janeiro: Elsevier, 2012.

MOORE, J. F. The death of competition: leadership and strategy in the age of business ecosystems. New York: HarperBusiness, 1996.

MORAES, R. P. Definição de um sistema de gestão de resíduos sólidos domésticos com compostagem para Londrina, PR. Orientador: Paulo Jorge Moraes Figueiredo. 2012. Tese (Doutorado) - Universidade Metodista de Piracicaba, UNIMEP, Santa Bárbara D’Oeste, SP, 2012.

NÓBILE, A. A. Diretrizes para a sustentabilidade ambiental em empreendimentos habitacionais. 2003. Dissertação (Mestrado em Engenharia Civil) - Universidade Estadual de Campinas, Campinas, SP, 2003.

ÖZKUL, Z. H.; BAYKAL, G. Shear behavior of compacted rubber. Journal of Geotechnical and Geoenvironmental Engineering, New York, US, v. 133, n. 7, p. $767-$ 781, jul. 2007. 
PEREIRA, A. M.; FAZZAN, J. V.; FREITAS, V. Análise da viabilidade do uso da fibra de borracha de pneu como reforço em tijolo de solo cimento. Revista Nacional de Gerenciamento de Cidades, [S. 1.], v. 3, n. 20, set. 2015. Disponível em: $<$ ://www.amigosdanatureza.org.br/publicacoes/index. php/gerenciamento_de_cidades/article/view/1056>. Acesso em: 12 dez. 2018.

REGINO, G. Como qualificar a mão de obra na construção civil: metodologia para atualização profissional no canteiro de obra. São Paulo: PINI, 2010.

RENUKAPPA, S.; EGBU, C.; GOULDING, A. A. J. A critical reflection on sustainability within the UK industrial sectors. Construction Innovation, UK, v. 12, n. 3, p. 317-334, 2012.

RIBEIRO, S. V.; HOLANDA, J. N. F. Soil-cement bricks incorporated with granite cutting sludge. Int J Eng Sci Innovative Technol, Chennai, v. 3, n. 2, p. 401-408, 2014.

ROCHA, J. C.; JOHN, V. M. Utilização de Resíduos na Construção Habitacional. Porto Alegre: Habitare, 2003. (Coletânea Habitare, v. 4).

SÁ, M.; GONCALVES, E. B.; BITTARELLO, K., LAPOLLI, É. M. Responsabilidade socioambiental: um desafio para a micro e pequena empresa. In: Simpósio de excelência em gestão e tecnologia, 10, 2013, Rio de Janeiro. Anais [...]. Rio de Janeiro: Assossiação Educacional Dom Bosco, 2013.

SÁFFARO, F. A. Uso da prototipagem para gestão do processo de produção da construção civil. 2007. Tese (Doutorado em Engenharia Civil) - Universidade Federal de Santa Catarina, UFSC, Florianópolis, SC, 2007.

SANTOS, H. P.; RITA DE CÁSSIA, S. S.; FASSONI, D. P. Tijolos de solo-cimento com incorporação de resíduo de tinta: uma alternativa que envolve indústria e sociedade em busca de soluções para problemas ambientais e habitacionais, Encontro Nacional, 4.; Latino-Americano Edificações e Comunidades Sustentáveis, 2., 2007, Campo Grande. Anais [...]. Campo Grande: ANTAC, 2007. p. $1-15$.

SAVITZ, A. The triple bottom line: how today's best-run companies are achieving economic, social and environmental success-and how you can too. Nova Jersey: John Wiley \& Sons, 2013.
SEGANTINI, A. A. S.; WADA, P. H. Estudo de dosagem de tijolos de solo-cimento com adição de resíduos de construção e demolição. Acta Scientiarum Technology, Maringá, v. 33, n. 2, p. 179-183, 2011.

SHAHIN, M. A.; HONG, L. S. Utilization of shredded rubber tires for cement-stabilized soft clays. In: PUPPALA, A.; HUANG, J.; HAN, J.; HOYOS, L. (ed.). Ground improvement and geosynthetics. GeoShanghai International Conference. Proceedings [...]. Shanghai: American Society of Civil Engineers. p. 181-186.

SHARRARD, A. L.; MATTHEWS, H. S.; RIES, R. J. Estimating construction project environmental effects using an input-output-based hybrid life-cycle assessment model. Journal of Infrastructure Systems, New York, v. 14, n. 4, p. 327-336, 2008.

SILVA, F. S.; CASTRO, P. A S. Incentivo ao uso de produtos de baixo impacto ambiental. São Paulo: CEUNSP, 2011.

SLAPER, T. F.; HALL, T. J. The triple bottom line: what is it and how does it work. Indiana business review, Greenwich, v. 86, n. 1, p. 4-8, 2011.

TRIPLE bottom line: it consists of three ps: profit, people and planet. The Economist, London, 17 nov 2009. IDEA.

VANCLAY, F. The triple bottom line and impact assessment: how do TBL, EIA, SIA, SEA and EMS relate to each other?. Journal of Environmental Assessment Policy and Management, Hackensack, v. 6, n. 3, p. 265-288, 2004.

VILHENA, A. Evolução da reciclagem no Brasil. In: Seminário Internacional Wastnet, 2009.

YONEYAMA, S. - Levantamento das Alternativas para Solucionar o Problema de Resíduos de Pneus. Trabalho de Conclusão de Curso em Engenharia Civil - Universidade Estadual de Londrina, 2002, Curitiba. Anais [...]. Curitiba, PR, 2002

Received: Feb. 25, 2019 Accepted: Apr. 29, 2019 